\section{JURNAL EKONOMI EFEKTIF}

ISSN : $2622-8882$, E-ISSN : 2622-9935

Jurnal Ekonomi Efektif, Vol. 3, No. 1, Oktober 2020 @Prodi Manajemen Fakultas Ekonomi Universitas

Pamulang

\title{
PENGARUH LINGKUNGAN KERJA DAN PENGEMBANGAN KARIER KARYAWAN TERHADAP KINERJA KARYAWAN PADA PT. TELKOM INDONESIA PERSERO. TbK
}

\author{
Bachtiar Arifudin Husain \\ Universitas Pamulang \\ dosen01773@unpam.ac.id
}

\begin{abstract}
ABSTRAK
Penelitian ini bertujuan untuk mengetahui bagaimana pengaruh Lingkungan Kerja $\left(\mathrm{x}_{1}\right)$ terhadap Kinerja Karyawan (y), pengaruh Pengembangan Karyawan $\left(\mathrm{x}_{2}\right)$ terhadap Kinerja Karyawan (y) dan pengaruh Lingkungan Kerja ( $\left.\mathrm{x}_{1}\right)$ dan Pengembangan Karyawan ( $\mathrm{x}_{2}$ ) secara bersama-sama terhadap Kinerja Karyawan (y) PT. Telkom Indonesia persero.Tbk , dimana variabel independen yang diteliti adalah Lingkungan Kerja $\left(\mathrm{x}_{1}\right)$ dan Pengembangan Karyawan $\left(\mathrm{x}_{2}\right)$, sedangkan variabel dependennya adalah Kinerja Karyawan $(\mathrm{y})$

Metode yang digunakan untuk penelitian ini adalah metode asosiatif dengan pendekatan kuantitatif. Populasi yang diambil yaitu karyawan PT. Telkom Indonesia persero. Tbk di Jakarta Selatan yang be rjumlah 73 orang dan teknik sampel yang digunakan adalah sampel jenuh yang seluruh populasi merupakan sampel dalam penelitian ini. Teknik Pengujian yang digunakan meliputi Uji Validitas, Uji Reliabilitas, Uji Asumsi Klasik (Normalitas, Multikolinearitas, Heteroskedastisitas, Autokolerasi), Analisis Regresi Linear Berganda, Koefisien Korelasi Product Moment, Koefisien Determinasi dan Uji Hipotesis (Uji T, Uji F).

Hasil penelitian data menunjukkan bahwa Lingkungan Kerja $\left(\mathrm{x}_{1}\right)$ dan Pengembangan Karyawan $\left(\mathrm{x}_{2}\right)$ berpengaruh positif dan signifikan terhadap terhadap Kinerja Karyawan (y) pada pada PT. Telkom Indonesia persero.Tbk Dari hasil uji t menunjukan nilai hasil uji t (parsial) pada variabel Lingkungan Kerja $\left(\mathrm{x}_{1}\right)$ menujukkan $\mathrm{t}_{\text {hitung }}(3.231)>\mathrm{t}_{\text {tabel }}(1.994)$ dengan nilai sig $0.037<0.05$ dan variabel Pengembangan Karyawan $\left(\mathrm{x}_{2}\right)$ menunjukkan thitung $(3.441)>$ tabel (1.994) dengan nilai sig $0.000<0.05$ serta dari hasil uji $\mathrm{f}$ secara simultan antara menujukkan bahwa nilai $\mathrm{f}_{\text {hitung }}(17.363)>\mathrm{f}_{\text {tabel }}(3.13)$ dan nilai sig $(0.000)<0.005$ sehingga $\mathrm{H}_{\mathrm{o}}$ ditolak dan $\mathrm{H}_{\mathrm{a}}$ diterima artinya baik secara parsial maupun simultan Lingkungan Kerja $\left(\mathrm{x}_{1}\right)$ dan Pengembangan Karir Karyawan $\left(\mathrm{x}_{2}\right)$ berpengaruh positif dan signifikan terhadap Kinerja Karyawan (y) pada PT. Telkom Indonesia persero.Tbk dan Melalui pengujian koefisien determinasi $\left(\mathrm{R}^{2}\right)$ diperoleh sebesar 0.332 sama dengan $33.2 \%$ sedangkan sisanya $66.8 \%$ dipengaruhi oleh faktor lain yang tidak diteliti.
\end{abstract}

\section{Kata Kunci : Lingkungan Kerja, Pengembangan Karier Karyawan dan Kinerja Karyawan.}




\begin{abstract}
This study aims to determine how the influence of the Work Environment (x1) on Employee Performance (y), the influence of Employee Development (x2) on Employee Performance ( $y$ ) and the influence of Work Environment (x1) and Employee Development ( $x 2)$ together on Performance. Employees (y) of PT. Telkom Indonesia persero. Tbk, where the independent variables studied are Work Environment (x1) and Employee Development (x2), while the dependent variable is Employee Performance ( $y$ )

The method used for this research is an associative method with a quantitative approach. The population taken is the employees of PT. Telkom Indonesia persero. Tbk in South Jakarta, amounting to 73 people and the sample technique used is a saturated sample where the entire population is the sample in this study. The testing techniques used include Validity Test, Reliability Test, Classical Assumption Test (Normality, Multicollinearity, Heteroscedasticity, Autocoleration), Multiple Linear Regression Analysis, Product Moment Correlation Coefficient, Determination Coefficient and Hypothesis Test (T Test, F Test).

The results of the data research indicate that the Work Environment (x1) and Employee Development (x2) have a positive and significant effect on Employee Performance (y) at PT. Telkom Indonesia persero.Tbk From the results of the t test shows the value of the t test (partial) on the Work Environment variable (x1) shows tcount (3.231)> t table (1.994) with a sig value of $0.037<0.05$ and the Employee Development variable ( $x 2)$ shows tcount ( 3.441$)>t$ table (1.994) with a sig value of $0.000<0.05$ and the results of the $f$ test simultaneously show that the value of fcount (17.363)> ftable (3.13) and the value of sig (0.000) $<0.005$ so that Ho is rejected and Ha is accepted, it means that both partially or simultaneously Work Environment $(x 1)$ and Employee Career Development (x2) have a positive and significant effect on Employee Performance (y) at PT. Telkom Indonesia persero.Tbk and through testing the coefficient of determination (R2) obtained 0.332 equal to $33.2 \%$ while the remaining $66.8 \%$ is influenced by other factors not examined.
\end{abstract}

Keywords: Work Environment, Employee Career Development and Employee Performance. 


\section{PENDAHULUAN}

\section{A. Latar Belakang Masalah}

Kinerja yang baik adalah yang sesuai standar organisasi dan mendukung tercapainya tujuan organisasi. Organisasi yang baik adalah organisasi yang berusaha meningkatkan kemampuan sumber daya manusianya, karena hal tersebut merupakan faktor kunci untuk meningkatkan kinerja karyawan.

Menurut Bangun (2013:231) Kinerja adalah hasil pekerjaan yang dicapai karyawan berdasarkan persyaratan-persyaratan pekerjaan. Oleh karena itu upaya untuk meningkatkan kinerja karyawan merupakan tantangan manajemen yang paling serius karena keberhasilan untuk mencapai tujuan dan kelangsungan hidup organisasi tergantung pada kualitas kinerja sumber daya manusia yang ada didalamnya. dengan berkembangnya waktu, dalam organisasi dituntut untuk dapat berkembang dan memberikan pelayanan yang terbaik termasuk organisasi.

Banyak faktor yang dapat mempengaruhi kinerja diantaranya adalah lingkungan kerja. Menurut Subekhi dan Jauhar (2013:34) lingkungan kerja sebagai seluruh elemen yang terdapat diluar batas-batas organisasi, yang mempunyai potensi untuk mempengaruhi bagian ataupun organisasi secara keseluruhan. Lingkungan kerja akan mempengaruhi para karyawan langsung maupun tidak langsung yang dapat mempengaruhi produktifitas organisasi. Sebaliknya lingkungan kerja yang tidak baik akan menurunkan kinerja para karyawan dan secara tidak langsung juga menurunkan produktifitas organisasi. Selanjutnya faktor lain yang dapat mempengaruhi kinerja adalah pengembangan karyawan. menurut Hasibuan (2017:69) menyatakan pengembangan adalah suatu usaha untuk meningkatkan kemampuan teknis, teoritis, konseptual, dan moral karyawan sesuai dengan kebutuhan pekerjaan/jabatan melalui pendidikan dan pelatihan. Pengembangan karyawan pada organisasi sangatlah dibutuhkan untuk meningkatkan kemampuan, dan moral karyawan sesuai kebutuhan melalui pendidikan dan pelatihan. dimana arus informasi dan perubahan begitu cepat dan kompleks, karyawan dituntut harus memiliki pengetahuan (knowledge) dan kemampuan (ability) memadai.

Berdasarkan observasi diketahui bahwa kondisi lingkungan kerja yang kurang kondusif serta minimnya pengembangan karyawan sangat berpengaruh dalam bekerja sehingga terlihat jelas dampak negatif yang membuat menurunnya kinerja karyawan. Di perusahaan tersebut tidak ada laporan mengenai kondisi lingkungan kerja, bagaimana keamanan dan kenyamanan serta tidak ada data yang menjelaskan apakah ada kecelakaan kerja atau tidak. Walaupun dari pengamatan langsung banyak info kecelakaan kerja tetapi tidak pernah didata atau dilaporkan. Ini tentunya sangat mempengaruhi kinerja kerja karyawan APJII. Karena tidak ada kepastian jaminan akan kondisi lingkungan kerjanya.

Tabel 1. Total Karyawan APJII Berdasarkan Tahun 2018

\begin{tabular}{|c|c|c|}
\hline No & Level Organisasi & Jumlah Karyawan \\
\hline 1 & Badan Pengurus Harian (BPH) & 42 \\
\hline 2 & Koordinator & 2 \\
\hline 3 & Kepala BPH & 1 \\
\hline 4 & Dewan Pengurus & 21 \\
\hline 5 & Dewan Pengawas & 73 \\
\hline \multicolumn{2}{|c|}{ Total } \\
\hline
\end{tabular}

Sumber: APJII Kantor Kuningan, 2018

Berdasarkan data yang dihimpun oleh peneliti saat melakukan observasi, jumlah karyawan APJII sebanyak 73 karyawan. Pemilihan subjek ini karena peneliti ingin mengetahui pengembangan karir karyawan dalam peningkatan kinerja perusahaan. 
Dilihat dari tabel dimana posisi pengurus harian jumlahnya sangat banyak yaitu 42 sedangkan koordinator hanya 2 orang, tentunya ini menyulitkan dalam pengawasan operasional kerja setiap harinya. Dan menurut pendapat peneliti disini ada masalah dalam pengembangan karir karyawan. Pengembangan karir sangat penting didalama memotivasi karyawan dalam bekerja, tanpa motivasi yang tinggi maka kecil kemungkinan kinerja karyawan akan tercapai. Hal ini diperkuat dengan data-data yang penulis dapatkan dari manajemen APJII. Berikut data yang didapat

Tabel 2. Data Promosi Karyawan APJII Berdasarkan Tahun 2018

\begin{tabular}{|c|c|c|c|c|}
\hline No & Tahun & $\begin{array}{c}\text { Jumlah } \\
\text { Karyawan }\end{array}$ & $\begin{array}{c}\text { Jumlah } \\
\text { Promosi }\end{array}$ & $\begin{array}{c}\text { Presentase } \\
\%\end{array}$ \\
\hline 1 & 2016 & 73 & 15 & $20,5 \%$ \\
\hline 2 & 2017 & 73 & 20 & $27,5 \%$ \\
\hline 3 & 2018 & 73 & 24 & $32,9 \%$ \\
\hline
\end{tabular}

Sumber : APJII Kantor Kuningan, 2018

Berdasarkan tabel 2. diatas, selama tahun 2016 sampai dengan tahun 2018, didalam perusahaan tersebut ada promosi, namun lebih banyak promosi dalam hal kompensasi bukan kenaikan jabatan. Sehingga pengembangan karir di Assosiasi Penyelenggara Jasa Internet Indonesia terlihat tidak berjalan dengan baik.

Tabel 3. Pengukuran Penilaian kinerja APJII Tahun 2018

\begin{tabular}{|c|l|c|c|c|}
\hline \multirow{2}{*}{ No } & \multirow{2}{*}{ Komponen } & \multicolumn{3}{|c|}{ Jumlah Pencapaian Pengukuran } \\
\cline { 3 - 5 } & & $\begin{array}{c}\text { Mencapai } \\
\text { Target }\end{array}$ & $\begin{array}{c}\text { Tidak } \\
\text { Mencapai } \\
\text { Target }\end{array}$ & $\begin{array}{c}\text { Persentase Tidak } \\
\text { Mencapai Target } \\
(\%)\end{array}$ \\
\hline 1 & Kualitas Pelayanan & 45 & 28 & $38,4 \%$ \\
\hline 2 & Hubungan Pelayanan & 50 & 23 & $31,5 \%$ \\
\hline 3 & Ketegasan & 63 & 10 & $13,7 \%$ \\
\hline 4 & Integritas & 55 & 18 & $24,7 \%$ \\
\hline 5 & Kerjasama & 58 & 15 & $20,5 \%$ \\
\hline 6 & Kepimpinan & 57 & 16 & $21,9 \%$ \\
\hline 7 & Motivasi Karyawan & 43 & 30 & $41,1 \%$ \\
\hline 8 & Pencapaian Kerja & 47 & 20 & $27,4 \%$ \\
\hline 9 & Prestasi Kerja & 47 & 26 & $35,6 \%$ \\
\hline 10 & Tanggung Jawab & 59 & 14 & $19,2 \%$ \\
\hline
\end{tabular}

Sumber : APJII Kantor Kuningan, 2018

Berdasarkan tabel 3. Kinerja Karyawan yang di dalam Asosiasi Penyelenggara Jasa Internet Indonesia (APJII) belum mencapai target yang diharapakan, bahkan di komponen motiviasi kerja mencapai 41\%. Banyak masalah yang mempengaruhi motivasi karyawan, dapat dari lingkungan kerjanya, kejelasan dari karirnya, kompensasi dan banyak hal lain yang mempengaruhinya. Dengan hasil penilaian seperti itu dapat dikatakan kualitas dan kuantitas pekerjaan karyawan belum sesuai harapan. Otomatis prestasi kerja karyawan tidak bisa dicapai, ini terlihat dari tabel kinerja dimana prestasi kerja yang belum dicapai adalah 35,6\%. Berdasarkan fenomena diatas penulis tertarik untuk melakukan penelitian tentang "Pengaruh Lingkungan Kerja Dan Pengembangan Karier Karyawan Terhadap Kinerja Karyawan Pada Asosiasi Penyelenggara Jasa Internet Indonesia ( APJII )". 


\section{B. Rumusan Masalah}

a. Bagaimana pengaruh lingkungan kerja terhadap kinerja karyawan PT. Telkom Indonesia Persero. Tbk?

b. Bagaimana pengaruh pengembangan karyawan terhadap kinerja karyawan PT. Telkom Indonesia Persero. Tbk?

c. Bagaimana pengaruh lingkungan kerja dan pengembangan karyawan secara simultan terhadap kinerja PT. Telkom Indonesia Persero. Tbk?

\section{Tujuan Penelitian}

a. Untuk mengetahui Lingkungan Kerja terhadap Kinerja Karyawan PT. Telkom Indonesia Persero. Tbk.

b. Untuk mengetahui Pengembangan Karyawan terhadap kinerja karyawan PT. Telkom Indonesia Persero. Tbk.

c. Untuk mengetahui Pengaruh Lingkungan Kerja Dan Pengembangan Karyawan secara simultan Terhadap Kinerja Karyawan PT. Telkom Indonesia Persero. Tbk.

\section{METODE PENELITIAN}

\section{Populasi}

Menurut Sugiyono (2016:80) mengemukakan bahwa populasi adalah wilayah generalisasi yang terdiri dari obyek atau subyek yang mempunyai kualitas dan karakteristik tertentu yang ditetapkan oleh peneliti untuk dipelajari dan kemudian ditarik kesimpulannya. Berdasarkan definisi diatas penulis dapat mengambil kesimpulan populasi bukan sekedar jumlah tetapi meliputi seluruh karakteristik yang dimiliki subjek atau objek. Populasi dalam penelitian ini adalah seluruh karyawan Asosiasi Penyelenggara Jasa Internet Indonesia (APJII) yang berjumlah 73 orang.

\section{Sampel}

Menurut Sugiyono (2017:215) yaitu "Sampel adalah jumlah dan karakteristik yang dimiliki oleh populasi tersebut". Sedangkan menurut Suharsini Arikunto (2014:131), berpendapat bahwa "Sampel adalah sebagian atau wakil populasi yang diteliti". Sampel yang digunakan dalam penelitian ini sebanyak 73 responden.

\section{Metode Pengumpulan Data}

\section{Data Primer}

Menurut Sugiyono (2016:137) data primer adalah sumber data yang langsung memberikan data kepada pengumpul data. Dalam penelitian ini dilakukan dengan cara observasi dan menyebarkan kuesioner kepada karyawan PT. Telkom Indonesia Persero. Tbk.

\section{a. Observasi}

Sutrisno Hadi (1986) dalam Sugiyono (2016:145) mengemukaan bahwa observasi merupakan suatu proses yang kompleks, suatu proses yang tersusun dari berbagai proses biologis dan psikologis. Dalam hal ini penulis melaksanakan pengamatan langsung terhadap PT. Telkom Indonesia Persero. Tbk. dimana pengamatan terbatas pada pokok permasalahan sehingga perhatian lebih fokus kepada data (riil) dan relevan.

\section{b. Angket atau Kuesioner}

Menurut Sugiyono (2016:142) Angket merupakan teknik pengumpulan data yang dilakukan dengan cara memberi seperangkat pertanyaan atau pernyataan tertulis pada kuesioner kepada responden untuk memberi jawaban nya yang dijawab oleh responden.Kuesioner yaitu sejumlah pernyataan yang diajukan kepada responden 
secara tertulis. Daftar pernyataan ditujukan terutama yang berkaitan dengan masalah yang diteliti dalam penelitian ini menyertakan keseluruhan jumlah populasi sebagai sampel. Dalam penelitian ini kuesioner yang dibuat berupa pertanyaan dengan jawaban mengacu pada skala likert: Sangat Tidak Setuju (bobot 1), Tidak Setuju (bobot 2), Kurang Setuju (bobot 3), Setuju (bobot 4) dan Sangat Setuju (bobot 5)

\section{Data Sekunder}

Menurut Sugiyono (2016:137) data sekunder adalah sumber yang tidak langsung memberikan data kepada pengumpul data. Misalnya, orang lain, dokumen maupun informasi data. Selain itu, data sekunder adalah data yang diperoleh dari sumber-sumber media dan elektronik seperti internet (bahan dari objek penelitian). Data sekunder dalam penelitian ini mencakup data historis sejarah perusahaan, jumlah karyawan, layanan dan hal lain yang menunjang materi penulisan. Selanjutnya menurut Sugiyono (2017:140) "Studi kepustakaan berkaitan dengan kajian teoritis dan referensi lain yang berkaitan dengan nilai, budaya dan norma yang diteliti dan penting dalam melakukan penelitian, hal ini dikarenakan penelitian tidak akan lepas dari literatur ilmiah". Dalam penelitian ini studi kepustakaan dilakukan dengan mencari landasan teoritis yang berhubungan dengan judul penelitian.

\section{Analisis Data}

\section{a. Uji Instrumen}

Menurut Sugiyono (2016:147) berpendapat "Dalam penelitian kuantitatif analisis data merupakan kegiatan pengumpulan data dari sumber-sumber yang diperoleh". Kegiatan dalam analisis data adalah dengan mengelompokkan data berdasarkan variabel dan jenisnya, mentabulasi data berdasarkan variabel, menyajikan data berdasarkan variabel yang diteliti, melakukan perhitungan untuk menjawab rumusan masalah, dan melakukan perhitungan untuk mengetahui keberpengaruhannya serta menguji hipotesis yang telah diajukan.

\section{1) Uji Validitas}

Menurut Sugiyono (2016:168) valid berarti alat ukur yang digunakan untuk mendapat data (mengukur) itu valid. Valid berarti instrument tersebut dapat digunakan untuk mengukur apa yang seharusnya diukur.

Untuk menguji validitas setiap instrumen, rumus yang digunakan adalah koefisien korelasi product moment sebagai berikut:

$$
r_{x y}=\frac{n \sum x y-\left(\sum x\right)\left(\sum y\right)}{\sqrt{\left\{n \sum x^{2}-\left(\sum x\right)^{2}\right\}\left\{n \sum y^{2}-\left(\sum y\right)^{2}\right\}}}
$$

Keterangan :

$r x y=$ Koefisien korelasi (r-hitung)

$\mathrm{n}=$ Sampel

$\mathrm{X}=$ Skor setiap butir pernyataan varians $\mathrm{X}$

$\mathrm{Y}=$ Skor setiap butir pernyataan varians $\mathrm{Y}$

$\Sigma X=$ Jumlah butir pernyataan varians

$\Sigma y=$ Jumlah butir pernyataan varians $\mathrm{Y}$

\section{2) Uji Realibilitas}

Menurut Sugiyono (2016:168), menyatakan bahwa reliabilitas adalah suatu pengukuran yang menunjukkan stabilitas dan konsistensi dari suatu variable yang mengukur suatu konsep untuk mengakses dari suatu pengukuran. Sugiyono (2016:168) menyatakan uji realibilitas dilakukan untuk menguji apakah jawaban dari responden konsisten atau stabil. Pengujian realibilitas ini menggunakan rumus 
Cronbatch Alpha. Suatu variabel penelitian dikatakan reliable apabila memenuhi kriteria sebagai berikut:

1) Jika Cronbatch Alpha $>0.6$ dikatakan reliable

2) Jika Cronbatch Alpha < 0.6 dikatakan unreliable

\section{b. Analisis Deskriptif}

Dalam penelitian ini, untuk pembobotan data, peneliti menggunakan skala pengukuran. Menurut Sugiyono (2016:95). Skala pengukuran merupakan kesepakatan yang digunakan sebagai acuan untuk menentukan panjang pendeknya interval yang ada dalam pengukuran akan menghasilkan data.

\section{c. Analisis Verikatif}

Analisis Kuantitatif adalah penelitian untuk menilai kondisi dari nilai pengaruh, dan signifikasi pengaruh tersebut. Menurut Sugiyono (2016:55) metode verikatif merupakan penelitian yang bertujuan untuk mengetahui hubungan antara dua variabel atau lebih. Dengan demikian dari hasil ini akan memberikan jawaban awal dari rumusan masalah mengenai pengaruh variabel independen terhadap variabel dependen.

\section{d. Uji Asumsi Klasik}

Uji asumsi klasik digunakan untuk mengetahui ketepatan sebuah data. Menurut Singgih Santoso (2015:342) berpendapat sebuah model regresi akan digunakan untuk melakukan peramalan sebuah model yang baik adalah model dengan kesalahan peramalan seminimal mungkin. Karena itu, sebuah model sebelumnya digunakan seharusnya memenuhi beberapa asumsi, yangn biasa disebut asumsi klasik.

\section{e. Uji Hipotesis}

Pengujian hipotesis dimaksudkan untuk menentukan apakah suatu hipotesis sebaiknya diterima atau ditolak. Menurut Sugiyono (2016:213) Hipotesis merupakan jawaban sementara terhadap rumusan masalah penelitian, oleh karena itu rumusan masalah penelitian biasanya disusun dalam bentuk kalimat pernyataan dalam sebuah kuesioner. Jika asusmsi atau dugaan tersebut di khususkan mengenai populasi tersebut yang dipelajari adalah data sampel. Hipotesis merupakan dugaan yang dibuat untuk suatu hal untuk menjelaskan hal tersebut.

\section{f. Analisis Koefisien Determinasi}

Koefisien determinasi adalah bagian dari keragaman total variabel Y (terikat) yang dapat diterangkan atau diperhitungkan oleh keragaman variabel $X_{1}$ dan $X_{2}$ (bebas), yaitu koefisien yang mengukur besarnya presentase konstribusi variasi $X_{1}$ dan $X_{2}$ terhadap Y

\section{g. Uji Simultan ( Uji F )}

Menurut Ghazali (2013:99) uji F dilakukan untuk mengetahui

pengaruh variabel-variabel independen secara simultan (bersama-sama) terhadap variabel dependen. Untuk mengetahui pengaruh bersama-sama (simultan) terhadap variabel dependen dilakukan dengan menggunakan uji $\mathrm{F}$ test yaitu dengan cara membandingkan antara $\mathrm{F}$ hitung dengan $\mathrm{F}$ tabel.

\section{h. Analisis Regresi Linier Berganda}

Metode analisis data yang dipakai dalam penelitian ini adalah metode regresi berganda. Dimana untuk mencapai tujuan pertama yaitu menganalisis Lingkungan Kerja dan Pengembangan Karyawan terhadap Kinerja Karyawan dengan menggunakan analisis regresi berganda. Menurut Sugiyono (2016:277), Regresi berganda dilakukan terhadap model lebih dari satu variabel bebas, untuk diketahui pengaruhnya terhadap variabel terikat. Regresi berganda dilakukan untuk mengetahui sejauh mana variabel bebas mempengaruhi variabel terikat. 


\section{HASIL PENELITIAN DAN PEMBAHASAN}

\section{Pengaruh Lingkungan Kerja Terhadap Kinerja Karyawan.}

Berdasarkan tanggapan responden atas pernyataan variabel lingkungan kerja menunjukan hasil baik yang diindikasikan dengan jawaban responden sangat setuju dan setuju sebesar $84 \%$ dengan skor rata-rata 4,06 .

Menurut Subekhi dan Jauhar (2013:34) lingkungan kerja sebagai seluruh elemen yang terdapat diluar batas-batas organisasi, yang mempunyai potensi untuk mempengaruhi bagian ataupun organisasi secara keseluruhan. Dan menurut penelitian terdahulu "Ni Made rena P, Yayu Indrawati dan I GPB Sasrawan M, yang berjudul Pengaruh Lingkungan Kerja Terhadap Kinerja Karyawan Di PT Mitra Global Holiday Jimbaran Bali, dapat disimpulkan bahan lingkungan kerja memiliki hubungan dan pengaruh yang positif terhadap kinerja karyawan".

Berdasarkan uji hipotesis dengan mengggunakan uji t, dapat diketahui Lingkungan Kerja memiliki koefisien beta bernilai positif sebesar 3,321 dengan $t_{\text {hitung }}$ sebesar 3,321 dan dengan nilai signifikan sebesar $0,002<0,05$. Dengan demikian maka dari hasil pengujian $H_{0}$ ditolak dan $H_{1}$ diterima. Hal ini menujukkan bahwa Lingkungan Kerja berpengaruh positif dan signifikan terhadap Kinerja Karyawan.

\section{Pengaruh Pengembangan karyawan Terhadap Kinerja Karyawan}

Berdasarkan tanggapan responden atas pernyataan variabel Pengembangan Karyawan menunjukan hasil baik yang diindikasikan dengan jawaban responden sangat setuju dan setuju sebesar 78\% dengan skor rata-rata 3,90.

Menurut Hasibuan (2017:69) menyatakan pengembangan adalah suatu usaha untuk meningkatkan kemampuan teknis, teoritis, konseptual, dan moral karyawan sesuai dengan kebutuhan pekerjaan/jabatan melalui pendidikan dan pelatihan. Dan menurut penelitian terdahulu "Abu Bakar, dkk (2016) Jurnal Manajemen yang berjudul Pengaruh Pengembangan Karyawan Terhadap Kinerja Pada Bank Sulselbar Cabang Palopo, dapat disimpulkan bahwa Pengembangan Karyawan berpengaruh signifikan terhadap kinerja”.

Berdasarkan uji hipotesis Pengembangan Karyawan memiliki koefisien beta bernilai positif sebesar 3,441, dengan nilai hasil thitung sebesar 3,441 dan nilai signifikan sebesar 0,001 <0,05. Dengan demikian maka $\mathrm{H}_{0}$ ditolak dan $\mathrm{H}_{1}$ diterima, hal ini menunjukkan bahwa pengembangan karyawan berpengaruh positif dan signifikan terhadap kinerja karyawan.

3. Pengaruh Lingkungan Kerja dan Pengembangan Karyawan Secara Bersama-sama Terhadap Kinerja Karyawan.

Berdasarkan tanggapan responden atas pernyataan variabel kinerja karyawan menunjukan hasil sangat baik yang diindikasikan dengan jawaban responden sangat setuju dan setuju sebesar $73 \%$ dengan skor rata-rata 3,84 .

Menurut Bangun (2013:231) Kinerja adalah hasil pekerjaan yang dicapai karyawan berdasarkan persyaratan-persyaratan pekerjaan. Dan menurut penelitian terdahulu "Octo Bayu Putra W, Jantje L Sepanh, dan Sjendry SR Loindong Jurnal yang berjudul Pengaruh Lingkungan Kerja, Pelatihan, dan Pemberdayaan Sumber daya Manusia Terhadap Kepuasan Kerja Karyawan Pada PT. Bank Sulutgo, dapat disimpulkan bahwa secara simultan lingkungan kerja, pelatihan dan pemberdayaan sumber daya manusia berpengaruh positif dan signifikan. Lingkungan kerja secara parsial tidak berpengaruh secara signifikan terhadap kepuasan kerja sedangkan pelatihan dan pemberdayaan sumber daya manusia secara parsialberpengaruh positif dan signifikan terhadap kepuasan kerja".

Berdasarkan pada hasil uji hipotesis menggunakan uji $F$. nilai $F_{\text {hitung }}>F_{\text {tabel }}$ atau $17,363>3,13$, hal ini juga diperkuat dengan $0,000<0,05$. Dengan demikian, hal ini 
menunjukkan bahwa terdapat pengaruh positif dan signifikan secara simultan antara lingkungan kerja dan pengembangan karyawan terhadap kinerja karyawan.

\section{PENUTUP}

\section{Kesimpulan}

Berdasarkan uraian pada bab-bab sebelumnya, dan dari hasil analisis serta pembahasan mengenai pengaruh Pengaruh Lingkungan Kerja Dan Pengembangan Karier Karyawan Terhadap Kinerja Karyawan Pada PT. Telkom Indonesia persero.Tbk, maka dapat diambil kesimpulan sebagai berikut:

Terdapat pengaruh positif dan signifikan antara lingkungan kerja terhadap kinerja karyawan dengan uji hipotesis diperoleh $\mathrm{t}$ hitung $>\mathrm{t}$ tabel atau $(3,231>1,994)$ dengan nilai signifikan sebesar $0,002<0,05$ sehingga $\mathrm{H} 0$ ditolak dan $\mathrm{H} 1$ diterima artinya terdapat pengaruh yang positif dan signifikan antara lingkungan kerja terhadap kinerja karyawan PT. Telkom Indonesia persero.Tbk.

Terdapat pengaruh positif dan signifikan antara pengembangan karyawan terhadap kinerja karyawan dengan uji hipotesis diperoleh $t$ hitung $>t$ tabel atau $(3,441>1,994)$ dengan nilai signifikan sebesar $0,001<0,05$ sehingga $\mathrm{H} 0$ ditolak dan $\mathrm{H} 2$ diterima artinya terdapat pengaruh yang positif dan signifikan antara pengembangan karyawan terhadap kinerja karyawan PT. Telkom Indonesia persero.Tbk

Terdapat pengaruh positif dan signifikan antara lingkungan kerja dan pengembangan karyawan terhadap kinerja karyawan dengan diperoleh persamaan regresi linier berganda $Y=5,586+0,397 X 1+0,438 X 2$. Nilai konstanta sebesar 5,586 dan koefisien regresi X1 0.397 dan X2 0,438 dimana koefisien regresi angkanya bernilai positif. Nilai koefisien korelasi sebesar 0,576 atau memiliki pengaruh yang sedang dan nilai koefisien determinasi sebesar 0,332 atau 33,2\% sedangkan sisanya sebesar $(100 \%$ $33,2 \%)=66,8 \%$ dipengaruhi faktor lain. Uji hipotesis diperoleh $t$ hitung $>t$ tabel atau $(17,363>3,13)$ hal ini juga diperkuat dengan $\rho$ value $<$ Sig. 0,05 atau $(0,000<0,05)$ dengan demikian $\mathrm{H} 0$ ditolak dan $\mathrm{H} 3$ diterima artinya terdapat pengaruh yang positif dan signifikan antara lingkungan kerja dan pengembangan karier karyawan terhadap kinerja karyawan pada PT. Telkom Indonesia persero.Tbk

\section{Saran}

Berdasarkan penelitian yang telah dilakukan, penulis mencoba memberikan beberapa saran yang diharapkan sebagai bahan masukan untuk PT. Telkom Indonesia persero.Tbk sebagai bahan pertimbangan dalam memberikan kebijakan-kebijakan dimasa yang akan datang terkait dengan masalah-masalah yang ditemukan dalam penelitian ini. Adapun saran-saran yang akan penulis berikan adalah sebagai berikut:

Variabel lingkungan kerja, indikator yang paling lemah adalah suara bising dimana hanya mencapai score 3,78. Untuk lebih baik lagi perusahaan harus bekerja sesuai dengan tujuan yang telah ditetapkan dan memperbaiki kembali agar perusahaan dapat mencapai tujuan yang maksimal dan juga harus bekerja sesuai dengan kemampuan yang dimiliki.

Variabel pengembangan karyawan, indikator yang paling lemah adalah kedisplinan karyawan dimana hanya mencapai score 3,88. Untuk lebih baik lagi perusahaan harus bekerja sesuai dengan tujuan yang telah ditetapkan agar perusahaan dapat mencapai tujuan yang maksimal dan juga harus bekerja sesuai dengan kemampuan yang dimiliki.

Variabel kinerja karyawan, indikator yang paling lemah adalah ketepatan waktu dimana hanya mencapai score 3,53. Untuk lebih baik lagi perusahaan harus bekerja sesuai dengan tujuan yang telah ditetapkan agar perusahaan dapat mencapai tujuan yang maksimal dan juga harus bekerja sesuai dengan kemampuan yang dimiliki. 
Pengaruh lingkungan kerja dan pengembangan karyawan terhadap kinerja karyawan sebesar 33,2\% nilai ini masih dapat ditingkatkan dengan cara meningkatkan sumber daya manusia yang lebih kompeten dalam bidangnya, bekerja secara tim dengan baik dan dan berdisiplin tinggi.

\section{DAFTAR PUSTAKA}

Abdullah, M (2014) Manajemen dan Evaluasi Kinerja Karyawan, Yogyakarta: Penerbit Aswaja Pressindo.

Dessler, G. (2006.) Manajemen Sumber Daya Manusia (Jilid II). Jakarta: Indeks.

George Terry R \& Rue, Leslie W. Rue (2016) Dasar-Dasar Manajemen, Jakarta Bumi Aksara.

Gerry Dessler (2016) Human Resources Management, Prenticehall, London: International Inc.

Hasibuan, Malayu S.P. (2016). Manajemen Sumber Daya Manusia. Edisi Revisi. Jakarta: PT Bumi Aksara.

Imam Ghozali (2017). “Aplikasi Analisis Multivariate Dengan Program SPSS”. Edisi Kelima. Semarang: Badan Penerbit Undip.

Istijanto (2014) “Riset Sumber Daya Manusia”. Jakarta: PT. Gramedia Pustaka

Jasmani, J., \& Paeno, P. (2019). The Effect of Leadership and Competence on Lecturer Performance and Its Implications on Student Learning Motivation at Pamulang University. International Journal of Advances in Social and Economics, 1(4).

Luthans Fred (2014) Organizational Behavior, Ney York: McGraw-Hill, New York.

Mangkunegara, Prabu Anwar. (2016). Evaluasi Kinerja SDM. Cetakan ke tujuh, PT Refika Aditama: Bandung.

Pranoto, P., Jasmani, J., \& Marayasa, I. N. (2019). Pelatihan Digital Marketing Untuk Peningkatan Perekonomian Anggota Karang Taruna Al Barkah Di Kampung Cicayur-Tangerang. Jurnal Pengabdian Dharma Laksana, 1(2), 250-258.

Prasada, D., Sunarsi, D., \& Teriyan, A. (2020). Pengaruh Etos Kerja Dan Kompensasi Terhadap Komitmen Organisasi Pada DHL Logistic Di Jakarta. JENIUS (Jurnal Ilmiah Manajemen Sumber Daya Manusia), 4(1), 51-60.

Robbins, P.S, \& Judge, A.T. (2003). Organizational Behavior. Jakarta: Salemba Empat. Sugiyono (2017), "Metode Penelitian Administrasi : dilengkapi dengan Metode $R \&$ $D$ ". Bandung: Alfabeta.

Sunarsi, D. (2018). Buku Ajar: Seminar Perencanaan Sumber Daya Manusia. Tangerang Selatan: Asmoro Mediatama

Sunarsi, D. (2018). Pengembangan Sumber Daya Manusia Strategik \& Karakterisrik Sistem Pendukungnya : Sebuah Tinjauan. Jurnal Ilmiah MEA (Manajemen, Ekonomi, \& Akuntansi), 2(3), 178 - 194

Veithzal Rivai (2015) Manajemen Sumber Daya Manusia Untuk Perusahaan, Jakarta: Raja Grafindo Persada.

Wibowo (2015) Manajemen Kinerja, Jakarta: PT. Raja Grafindo Persada

Yuangga, K. D., \& Sunarsi, D. (2018). The Influence of Procrastination and Low Time Management on Student Self Efficacy (at MA Soebono Mantofani). PINISI Discretion Review, 2(1), 85-92. 